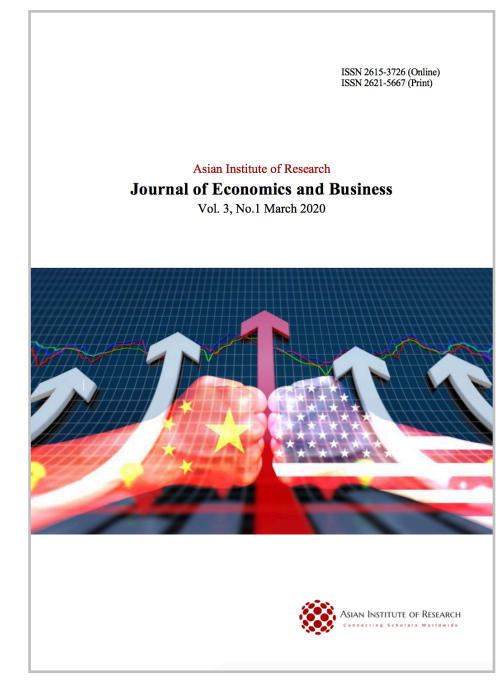

Journal of Economics and Business

Saleh, Mustaruddin. (2020), Empirical Testing of the Five-Factor Model of Fama and French in Indonesia as an Emerging Capital Market. In: Journal of Economics and Business, Vol.3, No.1, 19-28.

ISSN 2615-3726

DOI: 10.31014/aior.1992.03.01.175

The online version of this article can be found at: https://www.asianinstituteofresearch.org/

Published by:

The Asian Institute of Research

The Journal of Economics and Business is an Open Access publication. It may be read, copied, and distributed free of charge according to the conditions of the Creative Commons Attribution 4.0 International license.

The Asian Institute of Research Journal of Economics and Business is a peer-reviewed International Journal. The journal covers scholarly articles in the fields of Economics and Business, which includes, but not limited to, Business Economics (Micro and Macro), Finance, Management, Marketing, Business Law, Entrepreneurship, Behavioral and Health Economics, Government Taxation and Regulations, Financial Markets, International Economics, Investment, and Economic Development. As the journal is Open Access, it ensures high visibility and the increase of citations for all research articles published. The Journal of Economics and Business aims to facilitate scholarly work on recent theoretical and practical aspects of Economics and Business. 


\title{
Empirical Testing of the Five-Factor Model of Fama and French in Indonesia as an Emerging Capital Market
}

\author{
Mustaruddin Saleh ${ }^{1}$ \\ ${ }^{1}$ Department of Management, Faculty of Economics and Business, Tanjungpura University, PONTIANAK. \\ Email: mustaruddin@gmail.com
}

\begin{abstract}
This study was conducted to empirically examine the five-factor model of Fama and French in respect to stock returns of companies listed in the finance sector with 170 observations over the period 2012-2016. As a comparative analysis, this study is also conducted to examine CAPM and the three-factor model of Fama and French. The findings of the study revealed that the market return has a positive and partially significant impact on the stock return for CAPM. Specifically, both variables, small minus big (SMB) and high minus low (HML) have a positive and significant impact on stock returns in the three-factor model and five-factor model of Fama and French. In contrast to the research of Fama and French the explanation power of the five-factor model is lower than that of the three-factor model in this research.
\end{abstract}

Keywords: CAPM, Three-Factor Model, Five-Factor Model, Stock Returns

JEL Classifications: G3, G11

\section{Introduction}

In an effort to minimize the investment risk faced by investors for each investment portfolio, various theoretical models have been developed to explain the relationship between risk and return. The first model introduced was the capital asset pricing model (CAPM). This model is based on the portfolio theory proposed by Markowitz, where each investor is assumed to diversify their portfolio and choose the optimal portfolio on the basis of their preference for the level of profit and risk. The CAPM was first introduced by Sharpa (1964), Litner (1965), and Mossin (1966) in the mid-1960s; the model was very popular, and many empirical studies were carried out. The results of many empirical studies support the CAPM. Some empirical results include the studies of Black, Jensen, and Scholes (1972), and Fama and MacBeth (1973). Black et al. (1972), who tested the CAPM using time series data and cross-sectional data, found a positive relationship between beta and excess return. Fama and MacBeth (1973) provided support for the previous study by confirming that there is a positive and significant relationship between beta and excess return.

However, other empirical tests revealed that investment risk cannot be determined by a single factor (beta). As the research conducted by Fama and French (1992), Asgharian and Hansson (1998), Hodhosima et al. (2004), and Sandoval and Saens (2004) stated that there is no significant effect between beta stocks and stock returns, this researcher concluded that other variables are needed as additional variables to explain the relationship between 
risk and return. Thus, anomalies occur from the results of empirical testing of the CAPM. This is confirmed by the results of empirical studies that found that there is special volatility (Ang, Hodrick, Xing, and Zhang, 2006), liquidity risk (Pastor and Stambaugh, 2003, and momentum. As the results of the empirical studies above found that market beta is not able to explain the relationship between the rate of return and the risk of a securities portfolio, a multi-factor model was developed. This model, called the arbitrage pricing theory (APT) (Ross, 1976), stated that the return expectation of stocks might be influenced by several other sources of risk. This model is more efficient than the CAPM, and has been used extensively (Sudiyatno and Irsad (2011). The research of Fama and French (1996) revealed that the book-to-market ratio, firm size, and market return affect stock returns. This model became known as the three-factor model of Fama and French. Furthermore, empirical testing using three factors has been widely used in capital markets in developed countries as well as developing countries. In 2000, Davis, Fama and French (2000) re-tested the three-factor model, and found that beta, size, and book-to-market ratio had a significant influence on stock returns (Bodie et al., 2005). Other empirical studies that also used this model, found varied results, with not all factors being able to consistently explain stock returns; for example, beta had no significant effect, and firm-size and book-to-market ratio had a significant effect in China (Drew et al., (2003). Naughton and Veeraraghnavan's research found that only beta influenced and significantly affected stock returns in the three countries tested; namely, Indonesia, Taiwan, and Singapore (2005), while Charitou and Constantinidis (2007) found that the three variables, namely beta, firm size and book-to-market ratio had a significant effect on stock returns in the Japanese market.

The latest development is that Fama and French (2015) proposed two additional variables to their previous model; namely, the profitability variable and the investment patterns variable. Hence, the new model is called the fivefactor model of Fama and French. This model tries to explain the relationship between these new variables with the stock returns expected using the discounted dividend model perspective and valuation theory. Empirical testing of this five-factor model has been tried by Nguyen et al. (2015) in the capital market in Vietnam. The results of their study showed that there were quite high anomalies compared to the traditional asset valuation models; namely, CAPM and the three-factor model of Fama and French (1993). Nguyen et al. found that entering variable profitability and investment factors, showed superior results compared to the CAPM and three-factor model of Fama and French. This study conducts an empirical study of the five-factor model of Fama and French (2015) on Indonesia's Stock Exchange, where, to the author's knowledge, there has been limited empirical testing. This is understandable because the five-factor model was only recently published by the researchers. This research is deemed necessary as a contribution to the empirical testing of asset valuation models using the five-factor model of Fama and French.

Based on the background described, the formulation of the problem in this study is as follows: (1). Can the variation in the rate of return of shares on Indonesia's Stock Exchange be explained by CAPM? (2). Can the variation in returns on shares on Indonesia's Stock Exchange be explained using the three-factor model of Fama and French? (3). Can the variation in the rate of return of shares on Indonesia's Stock Exchange be explained using the five-factor model of Fama and French?

\section{Literature Review}

The investment goal for every investor is to maximize returns, without forgetting the investment risk factors that must be faced. Return is one of the factors that motivates investors to invest and is also a reward for the courage of investors to bear the risk of the investment made. According to eilly and Brown (2004: 4) investors invest funds from their savings and delay consumption to get a return on their investment. Investors will choose stocks that produce high returns with a high level of risk, and vice versa, stocks with low returns will have a lower risk.

\subsection{Single Index Model}

The single index model was developed by William Sharpe (1964), Lintner (1965), and Mossin (1966). According to Hartono (2014: 407) "a single index model is based on the observation that the price of a security fluctuates in the direction of the market price index." Stock prices tend to increase when the market price index increases, and vice versa. This shows that the profit level of a stock has a correlation with market changes (Husnan, 2001: 103). 
The single index model uses beta in measuring the sensitivity of the level of profit of a security against the level of profit from the market (Hartono, 2014: 409). The bigger the beta of a stock, the greater the market risk.

The capital asset pricing model (CAPM) is a model that shows the relationship between the expected profit and the risk of a stock or portfolio as measured by beta. The advantage expected by investors is based on two things; namely, compensation from the time value of money and risk premiums (Breadley et al., 2007). So, the expected level of profit from a security in the CAPM model is the return of risk-free assets as compensation for the time value of money plus risk premiums or additional implied profits based on the systematic risk of a security. The CAPM is based on the portfolio theory built by Markowitz, which is based on the assumption that each investor will diversify their portfolio and choose the optimal portfolio according to their preference for return and risk.

\subsection{Three-Factor Model of Fama and French}

The findings from the results of empirical studies reveal that there are contradictory results from the CAPM. The results of the study question the accuracy of the CAPM, which considers that beta is the only variable that explains the expected stock return. The previous studies found that deviations from risk, as measured by beta with stock returns, were also influenced by other variables. These variables are firm size (Banz, 1981), company profits (Basu, 1997 and 1983), leverage (Bhandari, 1988), and the book value to market value ratio (B/M) (Stattman, 1980, Rosenberrg et al., 1985; Chan et al., 1991). The results of the studies proved that there is a positive relationship between earnings, cash flow, and $\mathrm{B} / \mathrm{M}$ ratio with stock returns, and a negative relationship between company size and stock returns.

The research of Fama and French $(1992,1993)$ showed that company size and the B/M ratio have an important role in explaining the difference in the expected rate of return on cross-sectional non-financial companies. Furthermore, Barber and Lyon (1997) found that the relationship between size, B/M ratio, and rate of return is the same for financial and non-financial companies. They recommended an alternative model. The evidence suggests that the proxy size of the company and the $\mathrm{B} / \mathrm{M}$ ratio for the sensitivity of risk factors in the rate of return is consistent with rational-pricing for the role of company size in the average rate of return. The size of the company can be a proxy for the risk of negligence and $\mathrm{B} / \mathrm{M}$ can be an indicator of the relative prospects of the company (Pasaribu, 2009). Cochrane (1996 and 2001) stated that the asset pricing models that use portfolio returns as a factor may be able to explain asset return rates adequately; however, they have only been able to explain these factors partially because this model still leaves unanswered questions regarding returns based on factors (Pasaribu, 2009). Company size and B/M ratio are variables outside the CAPM, and research uses them as additional variables to clarify the relationship between risk and return in the CAPM. The results of the study conducted by Fama and French (1992) revealed that the B/M ratio and company size have a strong influence on the average return on shares. So, by entering the variable company size and B/M ratio into the model, the model is known as the threefactor model of Fama and French (1996).

\subsection{Five-Factor Model of Fama and French}

Criticism of the CAPM through the use of strict assumptions has led to this model being rejected and difficulty in applying it in real conditions. However, without ignoring the large contribution of the model in financial research, several other models have been developed to strengthen the explanation between risk and the rate of return on securities. Among them are the introduction of the many factor model from Ross (1976), which is popular with the term arbitrage pricing theory (APT). However, the weakness of APT is that it cannot provide guidance concerning what factors are relevant in influencing the returns on a stock. Then a three-factor model was developed by Fama and French (1992), which added to the CAPM model by including the variable size of the company and the $\mathrm{B} / \mathrm{M}$ ratio, thereby becoming a model of three factors - market returns, company size, and $\mathrm{B} / \mathrm{M}$ ratio. Furthermore, Carhart (1997) further examined the Fama and French three-factor model by including the variable impact of stock performance in the past on stock performance in the future, which became known as the fourfactor model. Carhart's model (1997) includes four variables in the model, market risk premium factors, firm size, $\mathrm{B} / \mathrm{M}$ and momentum ratio, and winner minus loser (WML). His research findings stated that the four-factor model 
can explain variations in portfolio returns based on past rates of return, and is consistent with the market model with four risk factors.

Multi-factor studies continue to be carried out by financial researchers, and the latest Fama and French (2015) research added two new variables to the three-factor model; namely, profitability and investment patterns. The two variables included were based on the results of various empirical studies that found that these two factors contributed to and affected asset returns (Hou, Xue, and Zhang, 2014; Novy-Max, 2013; and Titman et al., 2004). This model is known as the five-factor model of Fama and French. The results of the study by Fama and French (2015a and 2015b) showed that the ratio variable B/M places more emphasis on the explanation of the stock returns in the five-factor model. However, when testing on the international market, Fama and French (2015b) found that the five-factor model was more suitable for the North American and European markets and for large stock shares. Their findings also stated that there is a weak relationship for the rate of return of shares in the Japanese market. An empirical study with a five-factor model in emerging markets has been carried out by Nguyen et al. (2015) in the Vietnamese capital market. Their study found that the Fama and French five-factor model was better at explaining stock returns compared to the traditional CAPM model and the three-factor model. To the author's knowledge, no one has used the five-factor model of Fama and French for empirical studies in the Indonesian capital market. For this reason, this research is conducted to find empirical evidence to determine whether the new model provides a better explanation than the previous models.

\section{Research Method}

The population in this study is public companies listed in the Financial Sector of Indonesia's Stock Exchange for a period of 5 years from 2012 to 2016 . The research samples were taken by purposive sampling. In the estimation method the regression model using panel data can be done through three tests; to compare the performance of the CAPM with th three-factor model of Fama and French, and thea five-factor model from Fama and French. This method can use the ordinary least squares (OLS) approach or the least squares technique to estimate the panel data model. The regression equation can be written as follows:

Single Index Model; $R_{i, t}=\alpha+\beta_{i} R_{m, t}+e_{i, t}$

Three-Factor Model: $R_{I, t}=\alpha+\beta_{i} R_{m, t}+\beta_{i} S M B_{t}+\beta_{i} H M L_{t}+e_{i, t}$

Five-Factor Model: $R_{i, t}=\alpha+\beta_{i} R_{m, t}+\beta_{i} S M B_{t}+\beta_{i} H M L I, t+\beta_{i} P F_{i, t}+\beta_{i} I N V E S T I, t+e_{i, t}$

Where:

$$
\begin{aligned}
& \mathrm{Ri}, t=\text { portfolio return in period } t \\
& \mathrm{Rm}, t \quad=\text { market return, shows the JCI return, calculated from the stock price index } \\
& \text { with (IHSG) period } t \text {, minus IHSGt-1 return. } \\
& \mathrm{SMB}, t=\text { return on the factor "small minus big (SMB) in period } t \\
& \mathrm{HML}, t=\text { return on high minus low, book to market period } t \text {. } \\
& \mathrm{PF}, t \quad=\text { return on the profitability factor, that is, by dividing net income after tax } \\
& \text { with the book value of shareholders in period } t \text {. } \\
& \text { INVST, } t=\text { return on investment factor, which is calculated from the stock capitalization value } \\
& \text { circulating, and dividing investors into two groups; namely, the conservative investor } \\
& \text { group and the aggressive group of investors. }
\end{aligned}
$$

The regression coefficient here is very decisive as a basis for analysis, considering that this research is a fundamental method. This means that if the coefficient $\beta$ is positive $(+)$, then it can be said that there is a direct influence between the independent variable and the dependent variable. Each increase in the value of the independent variable will result in an increase in the dependent variable. Likewise, vice versa, if the coefficient of the value of $\beta$ is negative (-), this indicates a negative influence where the increase in the value of the independent variable will result in a decrease in the value of the dependent variable.

This study uses panel data regression analysis, so the selection of estimation models can be done through three approaches: (1) common effect model using the ordinary least squares (OLS) approach or the least-squares technique to estimate the panel data model. (2) the fixed-effect model, which assumes that differences between individuals can be accommodated from the difference in intercepts. This estimation model is often called the least 
squares dummy variable (LSDV) technique. (3) The random effect model which estimates panel data where interference variables may be interconnected between time and between individuals. The tests conducted to determine the right model can used a test tool, such as the (1) Lagrange multiplier test to find out whether the random effect model is better than the common effect method. (2) The Chow test or likelihood test for selection between the fixed effect models and common effects. Or (3) the Hausman test to choose whether the fixed effect model or random effect is the most appropriate to use.

\section{Results and Discussion}

\subsection{Descriptive Statistics Analysis}

Table 1 shows that the smallest value of the stock return rate, $\mathrm{Ri}$, is 0.0001 , while the highest value of $\mathrm{Ri}$, is 0.5301 . The average value of $\mathrm{Ri}$ is 0.0727 , which means that the value that represents the Ri data is $7.27 \%$. The standard deviation of $\mathrm{Ri}$ is $9.91 \%$, which indicates that the average deviation of the data from the data on average stock returns is $9,91 \%$. The highest monthly average return rate of $4.64 \%$ occurred in 2012 . This proves that the economic situation at that time was in a good and stable condition, and, hence, the community could increase consumption and investment, which continued to increase the company's performance. The lowest rate of return of $0.89 \%$ occurred in 2013 . The low monthly returns during the year were caused by less stable economic conditions, which had an impact on the declining company performance. If viewed per company, for five (5) years, the shares of three companies produced the highest monthly return in a row, these shares were those of PT. Atharvest Tbk, PT. Dayin Mitra Insurance, Tbk, and PT. Asuransi Harta Aman Pratama, Tbk, which were 30.21\%, $14.44 \%$, and $14.43 \%$, respectively.

Table 1. Descriptive Statistics

\begin{tabular}{lcccc}
\hline & Minimum & Maximum & Mean & $\begin{array}{c}\text { Std } \\
\text { Deviation }\end{array}$ \\
\hline Ri & Statistic & Statistic & Statistic & Statistic \\
Rm & 0.00010 & 0.53005 & 0.072704 & 0.099167 \\
SMB & 0.00030 & 0.01707 & 0.009690 & 0.005392 \\
HML & 0.00100 & 0.54867 & 0.079004 & 0.094417 \\
FP & -7.5100 & -0.61000 & -3.128500 & 1.172690 \\
INVST & -0.50339 & 0.50298 & 0.120973 & 0.007249 \\
& -0.52112 & 0.49268 & 0.029105 & 0.118912 \\
\hline
\end{tabular}

The market rate of return $(\mathrm{Rm})$ can be defined as the difference between the average of each month of all the shares with the rate of return of risk-free investment (risk-free rate). However, in this study, the market returns use the concept of reality returns, which are calculated based on historical data (Sudiyatno and Irsad, 2011). The lowest market return rate is 0.000030 or $0.03 \%$ and the highest is 0.01706 or $1.71 \%$. The development of monthly market returns is volatile and tends to decline. The highest monthly market return occurred in 2014 ; namely, $1.70 \%$ and the lowest occurred in 2015, which was $-0.97 \%$. This indicates that Indonesia's economic development in 2015 experienced a relatively significant decline. Judging from the growth of monthly returns, the highest monthly returns for the 5 years study period occurred in February and March, which were 3.63\% and 3.38\%, respectively.

The results of the SMB descriptive statistics show that the smallest value is 0.0010 , while the highest value of SMB is 0.5488 . The average value is 0.0790 , meaning that the value that represents the data is $7.90 \%$. The standard deviation is $1.17 \%$, which indicates that the average deviation of the data from the average SMB data is $9.44 \%$. The size of the company (firm size) in this study is proxied by SMB (small big minus). SMB is the difference between the average of each month of returns on small stock portfolios or small companies with the average of each month of return on large stock portfolios or big companies. The other variables are presented in table 1. 


\subsection{Regression Test Result}

In order to estimate the model with panel data, this study uses three alternative estimation models; namely, the common effect model (CEM), the fixed effect model (FEM), and the random effect model (REM). The third test results of the regression models used in the research are described in the following.

\subsubsection{Regression test model 1: CAPM}

The results of the t-test statistics for the CAPM model are shown below. The test results in Table 2 show that the market rate of return $(\mathrm{Rm})$ has an effect on the rate of return of shares in CEM, and has a significant partial effect on FEM and REM. This means that the portfolio returns in this research model can be explained by market returns at a significance level of $10 \%(\alpha=10 \%)$.

Table 2. Regression Test Result for CAPM

\begin{tabular}{lccc}
\hline & CEM & FEM & REM \\
\hline $\mathrm{C}$ & $0.0415^{* * *}$ & $0.0973^{* * *}$ & $0.0498^{* * *}$ \\
$\mathrm{Rm}$ & $(0.0000)$ & $(0.0000)$ & $(0.0000)$ \\
& $1.1197^{* * *}$ & $-2.5376^{*}$ & $2.3622^{*}$ \\
& $(0.0369)$ & $(0.0520)$ & $(0.0607)$ \\
\hline $\mathrm{R}^{2}$ & & & \\
$\mathrm{~F}-$ stat & 0.0219 & 0.2710 & 0.0146 \\
& $3.7549^{*}$ & $1.4762^{*}$ & 2.4929 \\
DW & $(0.0543)$ & $(0.0620)$ & $(0.1162)$ \\
CHOW-test & 1.9543 & 2.4813 & 1.7398 \\
& & $1.5204^{*}$ & \\
Hausman test & & $(0.0506)$ & 1.5369 \\
& & & $0.2151)$ \\
LM test & - & - & -
\end{tabular}

Notes: Dependent Variable: portfolio return in period, Ri,j; ${ }^{*} \mathrm{p}<0.10$; ${ }^{* *} \mathrm{p}<0.05$; and ${ }^{* * *} \mathrm{p}<0.0$; Figures in parentheses are standard robust to heteroscedasticity using White corrected; DW-statistic is Durbin-Watson $d$-test for autocorrelation; number of observation is 170 .

From the results of testing the three models above, regression testing using the random effect model (REM) is more appropriate because the results of the Chow-test are smaller than $\alpha=0.10$ and those of the Hausman test are greater than $\alpha=0.10$. The ability to vary the explanation of the independent variable on the dependent variable is very low (1.46 percent). This indicates that by using only one single variable in the CAPM model, the accuracy in explaining the effect of the relationship of the independent variable with the dependent variable is very limited.

\subsubsection{Regression Testing Model 2: Three-Factor Model of Fama and French.}

Table 3 above shows that from the three alternative models that appear, FEM is more appropriate for explaining the effect of the independent variable on the dependent variable in the three-factor model because the $\mathrm{F}$ value of the Chow-test and Hausman-test is smaller than $\alpha=0.05$. The test results of the three factors from Fama and French, showed that two factors have a significant positive effect on stock returns; namely, company size (SMB) and book value to market value (HML). This shows that the test results on the SMB variable have a statistically positive and significant effect on stock returns. This means that if each growth in size and book value against the market value of the company's stock is 1 , it will cause an increase in stock returns of 0.4019 and 0.6502 . The results of this test partially support the research conducted by Pasaribu (2009), in which the SMB and HML variables have a positive and significant effect on the portfolio of returns on shares on the Indonesian Stock Exchange. However, this is different from the results of the research conducted by Sudiyatno and Irsad (2011) who found that risk premiums; namely, market returns, have a positive effect and that two of the Fama and French factors cannot explain the behavior of stock returns in Indonesia.

Table 3. Regression Test Results for Three-Factor Model of Fama and French 


\begin{tabular}{lccc}
\hline & CEM & FEM & REM \\
\hline $\mathrm{C}$ & -0.0023 & $-0.0124^{* * *}$ & $-0.0052^{*}$ \\
& $(0.1640)$ & $(0.0003)$ & $(0.0892)$ \\
\hline $\mathrm{Rm}$ & $-0.3394^{* *}$ & 0.2662 & -0.2200 \\
& $(0.0429)$ & $(0.2997)$ & $(0.3415)$ \\
$\mathrm{SMB}$ & $0.4313^{* * *}$ & $0.4019^{* * *}$ & $0.5599^{* * *}$ \\
& $(0.0000)$ & $(0.0000)$ & $(0.0000)$ \\
$\mathrm{HML}$ & $0.5788^{* * *}$ & $0.6502^{* * *}$ & $0.4583^{* * *}$ \\
& $(0.0000)$ & $(0.0000)$ & $(0.0000)$ \\
\hline $\mathrm{R}^{2}$ & 0.9604 & 0.9777 & 0.9147 \\
F-stat & $1,342.831^{* * *}$ & $162.1691^{* * *}$ & $593.5539^{* * *}$ \\
& $(0.0000)$ & $(0.0000)$ & $(0.0000)$ \\
DW & 1.6576 & 2.2434 & 1.8202 \\
CHOW-test & & $5.0323^{* * *}$ & \\
& & $(0.0000)$ & \\
Hausman test & & & $\left(0.0109^{* *}\right.$ \\
& & & \\
LM test & & & \\
\hline
\end{tabular}

Notes: Dependent Variable: portfolio return in period, Ri,j; ${ }^{*} \mathrm{p}<0.10 ;{ }^{* *} \mathrm{p}<0.05$; and ${ }^{* * *} \mathrm{p}<0.0$; Figures in parentheses are standard robust to heteroscedasticity using White corrected; DW-statistic is Durbin-Watson $d$-test for autocorrelation; number of observation is 170 .

Furthermore, the $F$ statistic test aims to test whether all the independent variables included in the model have a joint influence on the dependent variable (Ghozali, 2013: 98). The simultaneous test results show that the calculated $F$ stat is 588,381 and that the $F$ table $(0.05 ; 3 ; 170)$ is 2.6049 . The test results show that, together, Rm, $\mathrm{SMB}$, and HML have a significant effect on stock returns. The coefficient of determination $\left(\mathrm{R}^{2}\right)$ is used to measure how far the ability of the model explains the variation of the dependent variable (Ghozali, 2013: 97). If the value of $\mathrm{R}^{2}$ approaches one it means that the independent variables provide almost all the information needed in explaining the dependent variable (Rustiono, 2008). In Table 3 the coefficient of determination $\left(R^{2}\right)$ is 0.914 and the adjusted $\mathrm{R}^{2}$ is 0.912 . In conclusion, the ability of $\mathrm{Rm}, \mathrm{SMB}$, and HML to explain stock returns is very high, which is equal to $91.20 \%$, while the remaining $7.07 \%$ is influenced by other factors.

\subsubsection{Regression Testing Model 3: Five-Factor Model from Fama and French.}

The following is a test for the Five-Factor Model of Fama and French (2015) in the Indonesian stock market, especially in companies in the financial sector. The t-statistics on this model are presented in Table 4 below. Based on the results of testing the t-statistics in Table 4, the results that are consistent with the testing of the Fama and French three-factor model; namely, the two LnSMB and LnHML variables in this model, are also significant and positive in explaining the variability in stock returns on the Indonesian Stock Exchange. Thus, the profitability and investment factor variables in the Fama and French five-factor model do not provide empirical evidence explaining the rate of return of shares on the Indonesian Stock Exchange. The results of this test are in line with the study conducted by Nguyen, Ulku., and Zhang (2015), and Fama and French (2015a) who stated that profitability and investment variables do not fully explain the relationship with the portfolio of stock returns if combined in a five-factor model. The results of the F statistical test, show that they have an influence and are significant on the stock returns. Furthermore, the variability of the independent variables in explaining the dependent variable, stock returns, is $48.20 \%$. 
Table 4. Regression Test Results for Five-Factor Model of Fama and French

\begin{tabular}{|c|c|c|c|}
\hline \multirow[b]{2}{*}{ Varible } & \multicolumn{3}{|c|}{ Model 1 (ROA) } \\
\hline & CEM & FEM & REM \\
\hline \multirow[t]{2}{*}{$\mathrm{C}$} & $-0.0029 *$ & $-0.0124 * * *$ & $-0.0065^{* *}$ \\
\hline & $(0.0833)$ & $(0.0003)$ & $(0.0436)$ \\
\hline \multirow[t]{2}{*}{$\mathrm{Rm}$} & -0.2719 & 0.3281 & -0.1701 \\
\hline & $(0.1090)$ & $(0.2554)$ & $(0.4896)$ \\
\hline \multirow[t]{2}{*}{ SMB } & $0.4297 * * *$ & $0.4147 * * *$ & $0.5487 * * *$ \\
\hline & $(0.0000)$ & $(0.0000)$ & $(0.0000)$ \\
\hline \multirow[t]{2}{*}{ HML } & $0.5822 * * *$ & $0.6299 * * *$ & $0.4700 * * *$ \\
\hline & $(0.0000)$ & $(0.0000)$ & $(0.0000)$ \\
\hline \multirow[t]{2}{*}{ PF } & $-0.0295 * *$ & $-0.0242 * *$ & -0.0146 \\
\hline & $(0.0281)$ & $(0.0281)$ & $(0.4967)$ \\
\hline \multirow[t]{2}{*}{ INVSTM } & 0.0089 & 0.0093 & 0.0326 \\
\hline & $(0.4414)$ & $(0.4439)$ & $(0.1363)$ \\
\hline $\mathrm{R}^{2}$ & 0.9684 & 0.9773 & 0.916 \\
\hline \multirow[t]{2}{*}{ F-stat } & $1,006.766^{* * *}$ & $148.5002 * * *$ & $358.3975 * * *$ \\
\hline & $(0.0000)$ & $(0.0000)$ & $(0.0000)$ \\
\hline DW & 1.6292 & 2.1845 & 1.7850 \\
\hline \multirow[t]{2}{*}{ CHOW-test } & & $4.9621 * * *$ & \\
\hline & & $(0.0000)$ & \\
\hline \multirow[t]{2}{*}{ Hausman test } & & & $10.5258^{*}$ \\
\hline & & & $(0.0616)$ \\
\hline
\end{tabular}

Notes: Dependent Variable: portfolio return in period, Ri,j; ${ }^{*} \mathrm{p}<0.10$; ${ }^{* *} \mathrm{p}<0.05$; and ${ }^{* * *} \mathrm{p}<0.0$; Figures in parentheses are standard robust to heteroscedasticity using White corrected; DW-statistic is Durbin- Watson $d$-test for autocorrelation; number of observation is 170

\section{Conclusion and Suggestion}

Based on the results of the data analysis and discussion in the previous section, the following conclusions have been derived. This study empirically tested the asset valuation models, the three-factor model of Fama and French, and the five-factor model of Fama and French on the portfolio of stock returns of financial sector companies on the Indonesian Stock Exchange. 34 companies were used as samples during the period of 2012 to 2016. The results of testing the CAPM model show that market returns have a positive and partially significant effect on the rate of return of shares of companies in the financial sector. The results of the testing of the three-factor model of Fama and French show that the Small Minus Big variable (SMB), as a proxy for company size (return), and the high minus low variable (HML), as a proxy for book value to market value (BE/ME), have a positive and significant influence on the rate of return of shares of companies in the financial sector. The results of testing the five-factor model from Fama and French show that only two of the five model variables; namely, the Small Minus Big variable (SMB), as a proxy for company size (Size), and the High Minus Low variable (HML), as a proxy for Book Value to Market Value (BE/ME), have a positive and significant effect on the rate of return of shares of companies in the financial sector. Variable market returns (Rm) in both models, namely, the three-factor model of Fama and French and the five-factor model of Fama and French did not affect the rate of return of shares of companies in the financial sector. In addition, the profitability factor (PF) and investment variable (Invst) in the five-factor model Fama and French have a negative effect but are not significant on the rate of return of shares of companies in the financial sector.

Based on the results of the data analysis of the three models in this study, the following are some of the suggestions given. As only two variables; namely, the SMB variable and the HML variable have a positive and significant influence on the three-factor model and the Fama and French five-factor model, it is recommended that investors make their investment decisions, prioritizing the companies which have a large size of return and a high ratio of book value of equity to the market value of equity. Considering that this research is limited to the use of a small 
sample size and focuses only on the financial sector, it cannot be generalized to other sectors; hence, it is suggested that further research be conducted to expand the sample size and use various sectors of the stock market.

\section{References}

Ang, A., Hodrick, R. J., Xing, Y., \& Zhang, X. (2006). "The cross-section of volatility and expected returns." Journal of Finance 61, 259-299.

Asgharian, Hossein \& Hansson, Bjorn (1998). "Cross Sectional Analysis of the Swedish stock market. http://www.nek.lu.se/publications/workpap.Paper/WP02 19.pdf. diakses 23 Agustus 2016.

Banz, Rolf W. (1981). "The Relationship Between Return and Market Value of Common Stock." Journal of Financial Economics. Vol. 9, pp. 3-18.

Basu, S. (1997). "Investment Performances of Common Stocks in Relation to Their Price Earnings Ratios: A Test of the Efficient Market Hypothesis." Journal of Finance, Vol. 12, pp. 129-156.

Basu, S. (1983). "The relationship between earnings yield, market value, and return for NYSE common stocks: Further evidence." Journal of financial economics 12, 129-156.

Bhandari, L, (1988). "Debt/Equity Ratio and Expected Common Stock Returns: Empirical Evidence." Journal of Finance, 43: 507-528.

Black, Fischer, Michael C. Jensen, Myron Scholes, (1972), The capital asset pricing model: Some empirical tests, in Studies in the Theory of Capital Markets. Jensen MC, ed. New York: Praeger. 79-121.

Bodie, Z. Kane, A. \& Marcus, A.J, (2005). “Investment”. Terjemahan Zuliani D. Dan Budi Wibowo. Jakarta Salemba Empat.

Carhart, Mark M., (1997), "On persistence in mutual fund performance," Journal of Finance, 52: 57-82.

Chan, L.K.C., Hamao, Y., Lakonishok, J., (1991). "Fundamentals and stock returns in Japan." Journal of Finance 46, 1739-1789.

Charitou, Andreas and Constantinidis, Eleni, (2004). "Size and Book-to-Market Factors in Earnings and Stock Returns: Empirical Evidence from Japan, (online), (http://www. business uiuc.edu/accountancy /research/vkz.center pers/Charitou.pdf. diakses 23 Agustus 2016.

Damar Hardianto dan Suherman, (2007). "Pengujian Fama-French Three-Factor Model di Indonesia." Jurnal Keuangan dan Perbankan, Vol. 13, No. 2 Mei, Hal. 198-208.

Davis James L., Eugene F. Fama, and Kenneth R. French, (2000), "Characteristics, covariances, and average returns: 1929-1997', Journal of Finance, 55:389-406.

Dede Irawan Saputra, (2008). "Perbandingan Fama and French Three Factor Model dengan Capital Asset Pricing Model." Jurnal Riset Akuntansi dan Keuangan, Vol. 4. No. 2 Agustus, Hal. 132-145.

Drew, Michael, E. Naughton, T., and Veeraraghavan, Madhu, (2003). "Firm Size, Book-to-Market Equity and Security Returns: Evidence from the Shanghai Stock Exchange." Australian Journal of Management, 28.2: 135-136.

Fama Eugene F, and James D. MacBeth. (1973), "Risk, return, and equilibrium: Empirical tests." Journal of Political Economy. 81:607-636.

Fama, E. F., \& French, K. R. (2015a.)"A five-factor asset pricing model." Journal of Financial Economics 116, $1-22$.

Fama, E. F., \& French, K. R., (015b). International tests of a five-factor asset pricing model. Working Paper. Retrieved from SSRN: ssrn.com/abstract=2622782 . diakses 23 Agustus 2016.

Fama, E.F., French, K.R. (1992). "The cross-section of expected stock returns." Journal of Finance 47, 427-465.

Fama, Eugene F., (1996), "Multifactor portfolio efficiency and multifactor asset pricing," Journal of Financial and Quantitative Analysis 31, 441-465.

Fama, Eugene F., dan Kenneth R. French. (1993). "Common risk factors in the returns on stocks and bonds." Journal of Financial Economics 33, 3-56.

Gujarati, D. 2003. Basic Econometric. Mc-Grawhill. New York.

Hodoshima, J. Garza, G.X. \& Kimura, M. (2000). "Cross Sectional Analysis of Return and Beta in Japan." Journal Economic and Business, 515-553.

Homsud, N., Wasunsakul, J., Phuangnark, S., and Joongpong, J, (2009). "A Study of Fama and French Three Factors Model and Capital Asset Pricing Model in the Stock Exchange of Thailand." International Research Journal of Finance and Economics, EuroJournals Publishing, Inc.

Isna Yuningsih dan Rizky Yudaruddin. (2007). "Pengaruh Model Tiga Faktor Terhadap Return Saham”. Akuntabilitas, September, Hal. 79-84.

Jegadeesh, N., Titman, S. (1993). "Returns to buying winners and selling losers: implications for stock market efficiency." Journal of Finance 48, 65-91.

Jogiyanto Hartono. (2003). “Teori Portofolio dan Analisis Investasi”. Yogyakarta : BPFE Yogyakarta. 
Lintner, John. 1(1965). "The valuation of risk assets and the selection of risky investments in stock portfolios and capital budgets," Review of Economics and Statistics 47, 13-37

Mossin, J. (1966). "Equilibrium in a Capital Asset Market." Econometrica 34(4), 768-783

Nguyen Nh., Ulku N., and Zhang J. (2015). The Fama-French five factor model: Evidence from Vietnam. Working Paper.

Novy-Marx, R. (2013). “The order side of value: The gross profitability premium.”, Journal of Financial Economics 108, 1-28.

Pastor, L., \& Stambaugh, R. F.,( 2003). "Liquidity risk and expected stock returns." Journal of Political Economy 111, 642-685.

Reilly, Frank, K., and Brown, Keith, (2004). "Investment Analysis and Portfolio Management." Seventh Edition, USA: South-Western.

Rosenberg, B., Reid, K. and Lanstein, R. (1985). "Persuasive evidence of market inefficiency." Journal of Portfolio Management 11, 9-17.

Ross, S, (1976). "The Arbitrage Pricing Theory of Capital Asset Pricing”. Jornal of Economic Theory 13: 341360 .

Sandoval, A. Eduardo \& Saens, N. Rodrig., Author (2004). "The Conditional Relationship Between Portfolio Beta and Return: Evidence from Latin America," Cuadernos de Economfa, 41. 4:65-89.

Sharpe, William F. (1964). Capital asset prices: A theory of market equilibrium under conditions of risk. Journal of Finance 19, 425-442.

Stock Market". http://www.nek.lu.se/publications/workpap Paper/WP02 19.pdf. diakses 23 Agustus 2016.

Sudiyatno B., dan Irsyad M. (2011). "Menguji model tiga faktor Fama dan French dalam mempengaruhi return saham studi pada saham LQ45 di Bursa Efek Indonesia". Jurnal Bisnis dan Ekonomi (JBE) 18 (2): 126136.

Tandelilin E. ((2010). Portofolio dan Investasi, teori dan aplikasi. Edisi Pertama, Penerbit Kanisius, Yogyakarta.

Titman, S., Wei, K., and Xie, F. (2004). "Capital investments and stock returns," Journal of Financial and Quantitative Analysis 39, 677-700. 